\title{
https://doi.org/10.46813/2021-131-065 \\ INFLUENCE OF METAL HYDRIDE HOLLOW CATHODE ON PENNING ION SOURCE OPERATION
}

\author{
I. Sereda, D. Ryabchikov, Ya. Hrechko, Ie. Babenko \\ V.N. Karazin Kharkiv National University, Kharkiv, Ukraine \\ E-mail: igorsereda@karazin.ua
}

\begin{abstract}
The influence of metal hydride hollow cathode on a Penning ion source operation has been carried out. The feature of investigation is hydrogen injection only due to its desorption from metal hydride under ion-stimulated processes. The regimes of optimal discharge operation in the hollow cathode mode are determined. It has been revealed that the transition to the hollow cathode mode occurs at lower voltages, the discharge works without external gas supply, and the working pressure in the cell is set at the level determined by the discharge current. The supply of a negative bias to the metal hydride hollow cathode weakly affects the features of the emission of axial particles, although it allows the increase of plasma density near the metal hydride hollow cathode.
\end{abstract}

PACS: $52.80 . \mathrm{Sm}$

\section{INTRODUCTION}

Gas discharge with a hollow cathode is believed to be a source of high electron flux and relatively low ion and neutral temperatures. It is widely applied in many industrial plasma devices like fluorescent lamps, electron or ion sources for modifying surfaces of solid bodies (etching, depositing thin films), in analytical and plasma chemistry [1]. Due to the partially bound of plasma by the cavity-like geometry and the reduction of electron loss a higher plasma density is achieved [1].

The choice of material for hollow cathode operation mainly depends on working gas and the field of application. For example, when working with heavy gases such as $\mathrm{Xe}$ the best materials are porous tungsten impregnated with $\mathrm{BaO}$ and lanthanum hexaboride $\left(\mathrm{LaB}_{6}\right)$, which are primary used for space applications [2]. When working on light gases, such as hydrogen isotopes, it is conveniently to use metal hydrides based on $\mathrm{ZrV}$ alloys, which are pre-saturated with hydrogen or it's isotopes. A significant reduction of thermal loads on such materials is achieved due to hydrogen desorption as a result of metal hydride thermal decomposition [3].
A decrease of surface sputtering was achieved due to the formation of protective gas target under metal hydride surface during the bombardment by high-energy heavy particles [3, 4].

Another advantage of metal hydride hollow cathode application is the desorbtion of neutral hydrogen locally at the cavity. Taking into account the excitation of hydrogen molecules on the surface of metal hydride the energy input can be reduced. It opens the way of compact, cheap and gas-feed-free device creation [5].

Taking into account the ability of a Penning discharge with a metal hydride cathode of emitting not only positive ions, but also negative particles in the axial direction $[6,7]$, we attempted to increase the brightness of the source by applying the hollow cathode effect.

\section{EXPERIMENTAL SETUP}

Experimental results were obtained on a Penning cell with a metal-hydride hollow cathode schematically shown in the Fig. 1.

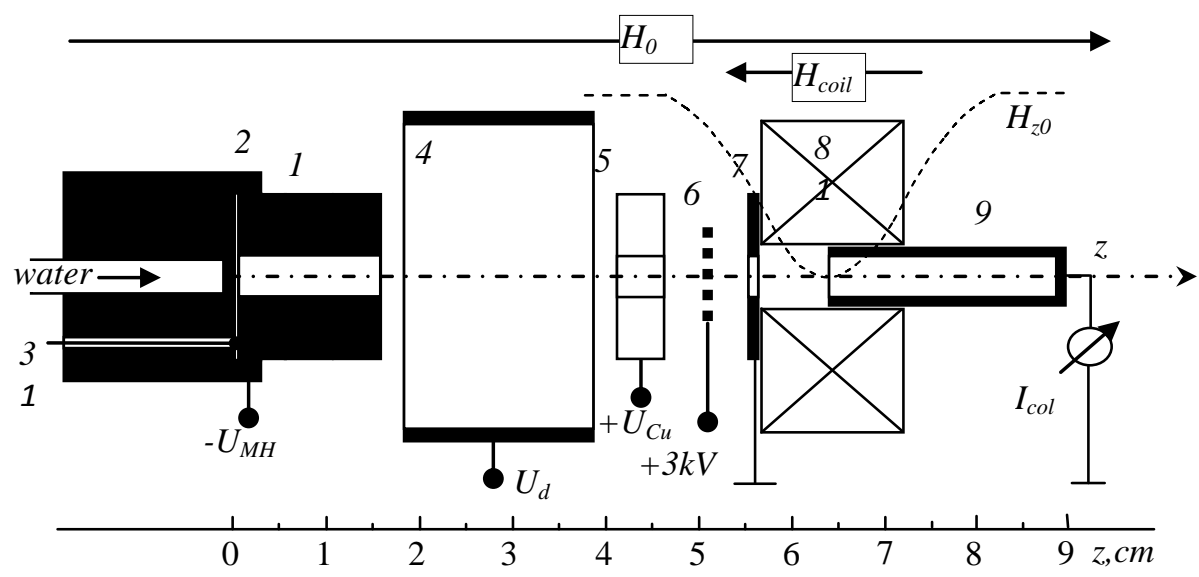

Fig. 1. The scheme of the Penning cell:

1 - metal hydride hollow cathode; 2 - cathode-holder with water-cool; 3 -thermocouple; 4 -anode; 5 -copper cathode-reflector with an aperture; 6 - reflecting grid; 7 -electrons collector; 8 -filter magnetic coil; $9-H$ ion collector; $H_{0}-$ main axial Penning magnetic field $\left(H_{0}=0 \ldots 0.1 \mathrm{~T}\right)$ 
The discharge cell consisted of a water-cooled metal hydride hollow cathode 1 , a tubular anode 2 , and a copper cathode-reflector 3 with a central aperture. Behind the aperture of the cathode-reflector was an electromagnetic filter 4 for negative ions registering. The calculation and design of the filter were discussed in [6].

The metal hydride hollow cathode 1 had a cylinder shape of $15 \mathrm{~mm}$ thick and $20 \mathrm{~mm}$ in diameter. The cavity was $5 \mathrm{~mm}$ in diameter. It was made by pressing a hydrogen-saturated powder $Z r_{50} V_{50}$ with a copper binder. The initial degree of hydrogen saturation was $\sim 1500 \mathrm{~cm}^{3}$ under normal conditions. The metal hydride hollow cathode had water cooling to stabilize the desorption rate of hydrogen. Its temperature in the experiments did not exceed $20{ }^{\circ} \mathrm{C}$, which is much lower than the decomposition temperature of the hydride phases (Fig. 2). Therefore, $\mathrm{H}_{2}{ }^{*}$ desorption was determined only by the discharge current and generally was provided by ion-stimulated processes on the surface of the metal hydride.

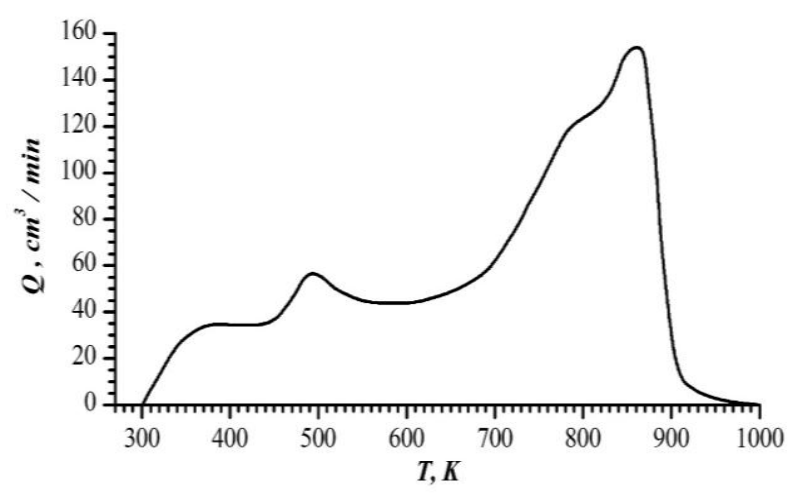

Fig. 2. The differential curve of hydrogen thermal desorbtion from Zr50V50 sample

Plasma parameters investigation was carried out with a Langmuir probe $4 \mathrm{~mm}$ in length and $0.3 \mathrm{~mm}$ in diameter. It was set in the axis of the discharge in a half distance between the anode 4 and the metal hydride cathode 1 . The cathodes were under grown potential, on the anode positive potential was supplied. A negative potential in the range from 0 to $-250 \mathrm{~V}$ can be supplied to the metal hydride cathode.

\section{RESULTS AND DISCUSSION}

One of the advantages of metal hydrides application as a material for a hollow cathode is the ability of a discharge operation without external hydrogen injection. It is achieved by hydrogen desorption from metal hydride locally into the plasma region due to thermal and ion-stimulated processes [8]. But the problem is the uncontrolled velocity of hydrogen desorption that do not allow of working pressure stabilization. The solution could be the temperature control of metal hydride below the minimum temperature of hydride phases decomposition. It is approximately $80^{\circ} \mathrm{C}$ for $\mathrm{ZrV}$ alloy used in our experiments. The cooling scheme of the metal hydride cathode had been previously implemented in $[6,7]$ and was also applied in this work.
Fig. 3 shows the current-voltage characteristics of a Penning discharge with a metal hydride hollow cathode. It transits to hollow cathode mode from the pressure of $p=2 \cdot 10^{-4}$ Torr. This pressure value is about three times less than for copper cathodes application [5]. An increase in the magnetic field also facilitates this transition.

The transition is accompanied by a drastic jump of discharge current, a thermal load on the metal hydride cathode and a rapid increase of hydrogen desorption rate. The metal hydride temperature control eliminates the uncontrolled thermal hydride phases decomposition, and hydrogen desorption will be determined only by ion-stimulated processes from the cathode surface. The pressure jump during the transition to the hollow cathode mode turns out not so fatal. However, the main result of this scheme is the ability of the stable discharge operation in a hollow cathode mode without external hydrogen injection. When the discharge current $I_{d}$ exceeded $10 \mathrm{~mA}$ and the discharge transited to a hollow cathode mode, the external injection of balloon hydrogen was switched off. The working pressure in the cell automatically was set to a stable level, which was determined by the rate of hydrogen desorption under the influence of ion bombardment of the cathode surface. A change in the discharge current leads to a synchronous change in pressure (Fig. 4). The upper value of discharge current $I_{d}$ of $100 \mathrm{~mA}$ was limited by the power supply unit used in the experiment, and the lower value of $30 \mathrm{~mA}$ - by the minimum pressure, when the hollow cathode mode still exists. Thus, at $I_{d}>30 \mathrm{~mA}$ the hollow cathode mode exists without external gas supply, and the operating pressure is set at the level determined only by the discharge current.

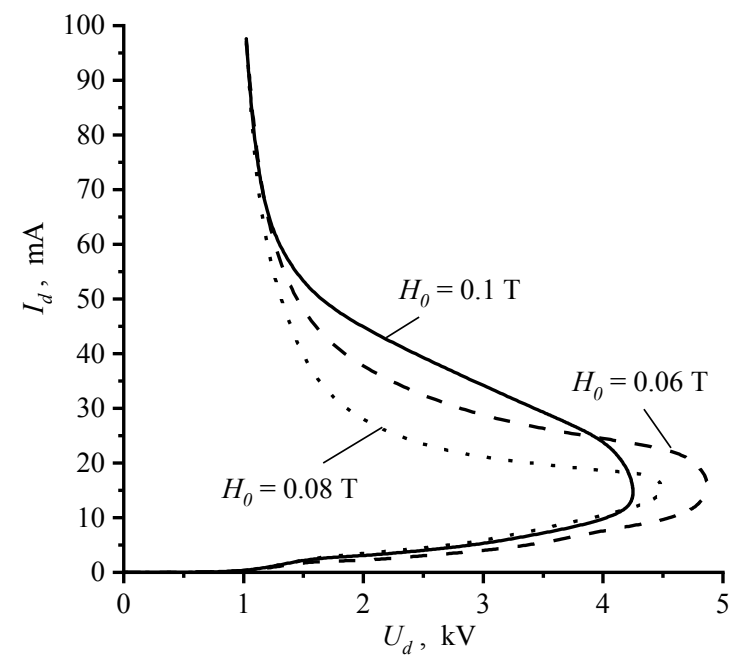

Fig. 3. Discharge current $I_{d}$ versus discharge voltage $U_{d}$ at started pressure $p=2 \cdot 10^{-4}$ Torr

Emission ability of the discharge demonstrated significant change (Fig. 5). If for $I_{d}<10 \mathrm{~mA}$ predominantly negative current of axial particles is detected. The transition to the hollow cathode mode reverses the situation. Positive ions prevail in the extracted flow, whose energy is close to $e U_{d}$ [5]. 


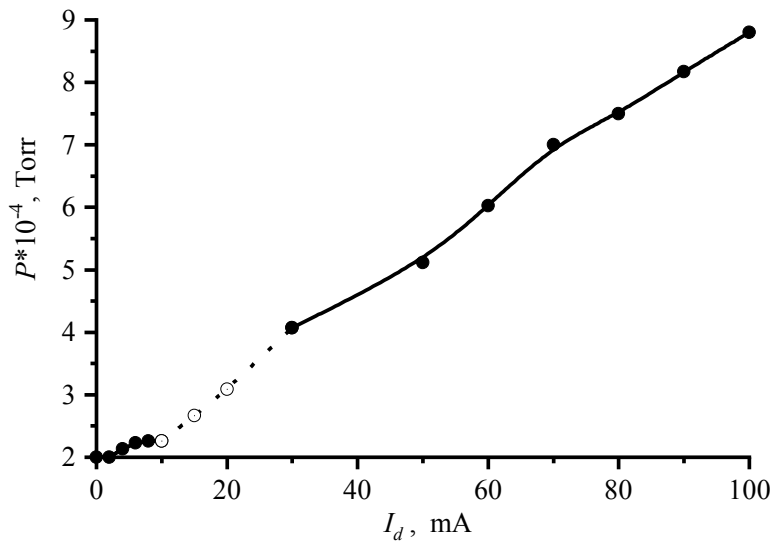

Fig. 4. Pressure $p$ versus discharge current $I_{d}$

This phenomenon can be explained as follows. The high-voltage mode of a Penning discharge is characterized by the existence of thick anode layer, where the most of supplied voltage $U_{d}$ concentrates. So, the potential in the cathode layer usually does not exceed $0.02 \cdot e U_{d}$ [9] and negative particles can freely yield in the longitudinal direction. The electric field of a grid 6 (see Fig. 1) also apparently distorts the distribution of the cathode potential and facilitates the extraction of negative particles even more.

In the high-current mode when $I_{d}>30 \mathrm{~mA}$ the voltage drops mainly in the cathode layers, and negative particles are mainly reflected from the cathode potential barrier back to the plasma and positive total collector current is detected. Here the number of $\mathrm{H}^{-}$ions is small; accordingly, the recorded $\mathrm{H}^{-}$current in hollow cathode mode is also significantly lower than in previous case.

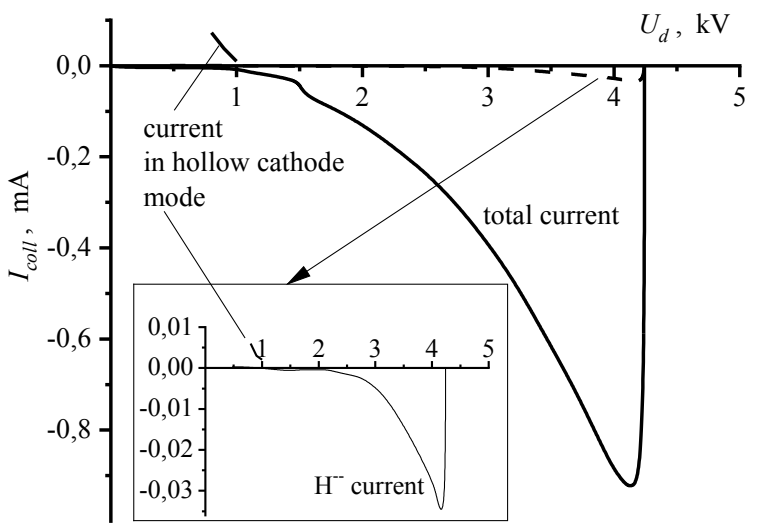

Fig. 5. Axial current on the collector $I_{\text {coll }}$ versus discharge voltage $U_{d}$ at $H_{0}=0.1 \mathrm{~T}, p=2 \cdot 10^{-4} \mathrm{Torr}$

A negative bias supply to the metal hydride hollow cathode weakly impacts the specific features of axial particles emission, although it slightly increases the plasma density $n$ near the metal hydride hollow cathode (Fig. 6). The electron temperature $T_{e}$ decreases in this case.

Fig. 7 demonstrates the ion current distribution on the sections of the hollow cathode. One can see that plasma penetrates into the metal hydride hollow cathode deeper, but with the smaller currents value on the cathode sections.
It can be explained by hydrogen desorbtion due to the ion bombardment. Hydrogen concentration in the hollow locally increases, as a result the conditions of plasma penetration into the hollow deeper are provided. The lower magnitudes of ion current on the sections of metal hydride hollow cathode at the same discharge current can be explained because of coefficient of secondary ion-electron emission for metal hydride is lower than for copper and depends on metal hydride saturation degree.

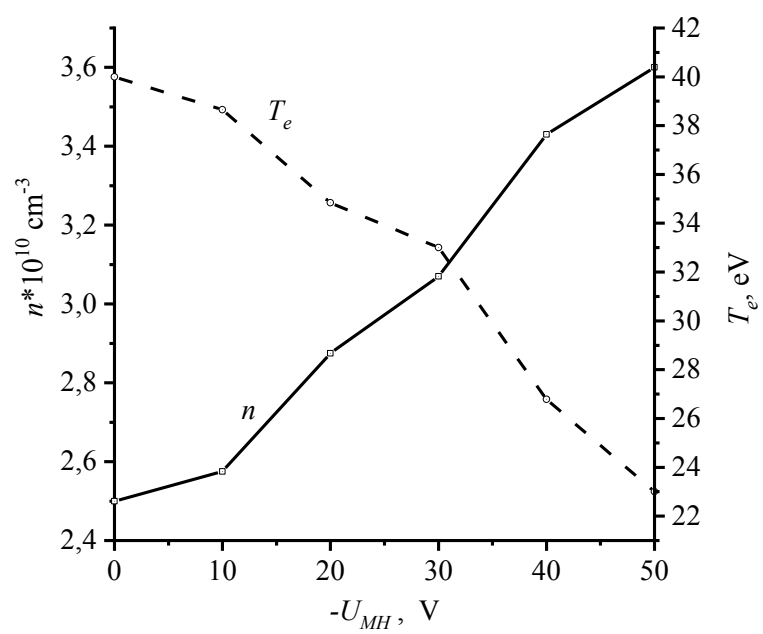

Fig. 6. Plasma density $n$ and electron temperature $T_{e}$ versus negative shift on metal hydride cathode $U_{M H}$ at $H_{0}=0.1 \mathrm{~T}, U_{d}=1.2 \mathrm{kV}, I_{d}=50 \mathrm{~mA}, p=5 \cdot 10^{4}$ Torr

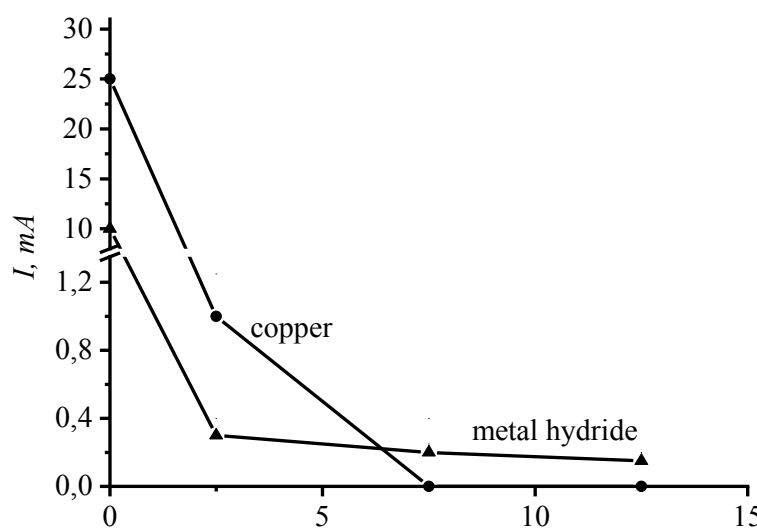

Fig. 7. Current distribution along the hollow cathode $H_{0}=0.1 \mathrm{~T}, U_{d}=1.2 \mathrm{kV}, I_{d}=50 \mathrm{~mA}, p=5 \cdot 10^{4}$ Torr

The supply of negative electrical bias on metal hydride cathode linearly increases the current value on the sections of metal hydride hollow cathode so that plasma density $n$ rises.

\section{CONCLUSIONS}

Thus, the cooling of metal hydride ensures hydrogen desorption only by ion-stimulated processes from the cathode surface. The transition to the hollow cathode mode occurs at lower voltages, the minimum pressure when the discharge transits to the hollow cathode mode here is $p=2 \cdot 10^{-4}$ Torr, which is about from two to three times less than for copper cathodes application. 
At $I_{d}>30 \mathrm{~mA}$ the hollow cathode mode exists without external gas supply, and the operating pressure is set at the level determined only by the discharge current.

In high-voltage mode predominantly negative current of axial particles is detected, but in hollowcathode mode the situation changes and positive collector current is detected.

The supply of a negative bias to the metal hydride hollow cathode weakly affects the features of the emission of axial particles, although it allows the increase of plasma density near the metal hydride hollow cathode.

\section{REFERENCES}

1. S. Muhl, A. Perez. The use of hollow cathodes in deposition processes: A critical review // Thin Solid Films. 2015, v. 579, p. 174-198.

2. I. Sereda, A. Tseluyko, N. Azarenkov. The Application of Metal Hydride Based on Zr-V Alloy in Hydrogen Plasma. In: Patrick C. Dam, editor. Hydrides: Types, Bonds and Applications, New York: "Nova Science Publishers Inc", 2018, p. 149-192.

3. D.M. Goebel, R.M. Watkins, and K.K. Jameson. $\mathrm{LaB}_{6}$ Hollow Cathodes for Ion and Hall Thrusters // Journal of Propulsion and Power. 2007, v. 23(3), p. 552.

4. V.N. Borisko et al. Hydrogen, and Helium Recycling at Plasma Facing Materials // Editor A. Hassanein,
Nato Science Series II: mathematics, physics and chemistry, Norwell MA: "Kluwer Academic Publishers", 2002, v. 54, p. 205-212.

5. V.N. Borisko, Ye.V. Klochko, I.N. Sereda, A.F. Tseluyko, D.V. Zinov'ev. Investigation of reflecting discharge with the sectioned metal-hydride hollow cathode // Problems of Atomic Science and Technology. Series «Plasma Physics» (10). 2005, № 1, p. 95-97.

6. I. Sereda, A. Tseluyko, D. Ryabchikov, Ya. Hrechko, N. Azarenkov. Effect of metal-hydride hydrogen activation on longitudinal yield of negative ions from PIG // International Journal of Hydrogen Energy. 2017, v. 42/34, p. 21866-21870.

7. I.N. Sereda, Ya.O. Hrechko, D.L. Ryabchikov, A.F. Tseluyko, N.A. Azarenkov. The increasing of $\mathrm{H}^{-}$ current from Penning ion source with electrically biased metal hydride cathode // Vacuum. 2019, v. 162, p. 163-167. 8. V.N. Borisko, Ye.V. Klochko, I.N. Sereda, A.F. Tseluyko. Activated hydrogen influence on characteristics of penning discharge with hollow cathode // Problems of Atomic Science and Technology. Series «Plasma Electronics and New Methods Acceleration» (5). 2006, № 5, p. 95-99.

9. I. Brown. The Physics and Technology of Ion Sources. Mörlebach: "Wiley-VCH Verlag GmbH and Co. KGaA", 2004.

\title{
ВЛИЯНИЕ МЕТАЛЛОГИДРИДНОГО ПОЛОГО КАТОДА НА РАБОТУ ПЕННИНГОВСКОГО ИОННОГО ИСТОЧНИКА
}

\author{
И. Середа, Д. Рябчиков, Я. Гречко, Е. Бабенко
}

Исследовано влияние металлогидридного полого катода на работу источника ионов Пеннинга. Особенностью исследования является инжекция водорода только за счет его десорбции из металлогидрида под действием ионно-стимулированных процессов. Определены режимы оптимальной работы разряда в режиме полого катода. Выявлено, что переход в режим полого катода происходит при более низких напряжениях, разряд работает без внешней подачи газа, а рабочее давление в ячейке устанавливается на уровне, определяемом током разряда. Подача отрицательного смещения на полый катод из гидрида металла слабо влияет на особенности эмиссии аксиальных частиц, хотя позволяет увеличить плотность плазмы вблизи металлогидридного полого катода.

\section{ВПЛИВ МЕТАЛОГІДРИДНОГО ПОРОЖНИСТОГО КАТОДА НА РОБОТУ ПЕННІНГОВСЬКОГО ІОННОГО ДЖЕРЕЛА}

\section{І. Середа, Д. Рябчиков, Я. Гречко, С. Бабенко}

Досліджено вплив металогідридного порожнистого катода на роботу джерела іонів Пеннінга. Особливістю дослідження є інжекція водню тільки за рахунок його десорбції з металогідриду під дією іонно-стимульованих процесів. Визначено режими оптимальної роботи розряду в режимі порожнистого катода. Виявлено, що перехід у режим порожнистого катода відбувається при більш низькій напрузі, розряд працює без зовнішньої подачі газу, а робочий тиск в осередку встановлюється на рівні, що визначається струмом розряду. Подача негативного зсуву на порожнистий катод з гідриду металу слабо впливає на особливості емісії аксіальних частинок, хоча дозволяє збільшити щільність плазми поблизу металогідридного порожнистого катода. 